\title{
Severity of melon powdery mildew as a function of increasing temperature and carbon dioxide concentration
}

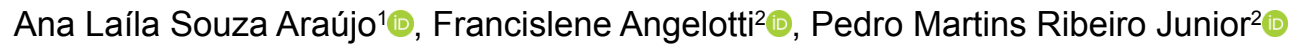 \\ 1 Universidade de Pernambuco, Mestrado em Ciência e Tecnologia Ambiental para o Semiárido, Petrolina-PE, Brasil. E-mail: laila.souzaraujo@yahoo.com.br \\ ${ }^{2}$ Embrapa Semiárido, Petrolina-PE, Brasil. E-mail: francislene.angelotti@embrapa.br; pedro.ribeiro@embrapa.br
}

ABSTRACT: The increase of $\mathrm{CO}_{2}$ and temperature may affect the progress of plant diseases. In this sense, the objective of this study was to evaluate the impact of increased carbon dioxide concentrations and temperature on melon powdery mildew. The experiments were performed in Fitotron growth chambers, with temperature, humidity and light control. The seedlings were submitted to two temperature regimes $\left(20-26-33^{\circ} \mathrm{C}\right.$ and $\left.24-30-37^{\circ} \mathrm{C}\right)$ and two $\mathrm{CO}_{2}$ concentrations $(410$ and $770 \mathrm{ppm})$. Nine melon cultivars (Araguaia, Awton, Eldorado, Gladial, Gold, Hibix, Natal, Juazeiro and Sancho) were evaluated. Melon seedlings were sprayed with a conidial suspension and maintained under controlled conditions to assess the disease progress. Along with the last severity assessment, conidia quantification was performed. The increase in temperature and $\mathrm{CO}_{2}$ concentration, as well as the interaction of these factors, reduces the severity of melon powdery mildew and the sporulation of Oidium sp. The incubation period of melon powdery mildew increases with an increase in $\mathrm{CO}_{2}$ concentrations and temperature.

Key words: climate change; $\mathrm{CO}_{2}$; Cucumis melo L.; cultivars; Oidium sp.

\section{Severidade do oídio do meloeiro em função do aumento da temperatura e da concentração de dióxido de carbono}

RESUMO: A elevação do $\mathrm{CO}_{2}$ e da temperatura podem afetar o progresso de doenças de plantas. Nesse sentido, o objetivo deste estudo foi avaliar o impacto do aumento da concentração de dióxido de carbono e da temperatura sobre o oídio do meloeiro. Os experimentos foram realizados em câmaras de crescimento, do tipo Fitotron, com controle de temperatura, umidade e luz. As plântulas foram submetidas a dois regimes de temperatura $\left(20-26-33^{\circ} \mathrm{C}\right.$ e $\left.24-30-37^{\circ} \mathrm{C}\right)$ e a duas concentrações de $\mathrm{CO}_{2}$ (410 e 770 ppm). Foram utilizadas nove cultivares de meloeiro Araguaia, Awton, Eldorado, Gladial, Gold, Hibix, Natal, Juazeiro e Sancho. As plântulas do meloeiro foram pulverizadas com uma suspensão de conídios e mantidas em condições controladas para avaliar o progresso da doença. Juntamente com a última avaliação da severidade foi realizada a quantificação de conídios. $\mathrm{O}$ aumento da temperatura e da concentração de $\mathrm{CO}_{2}$, assim como a interação desses fatores, reduz a severidade do oídio do meloeiro e a esporulação de Oidium sp., com resposta diferenciada para as cultivares de meloeiro, com severidade de $50 \%$, indicando alta suscetibilidade. 0 período de incubação do oídio do meloeiro aumenta com o incremento de $\mathrm{CO}_{2}$ e aumento da temperatura.

Palavras-chave: mudança climática; $\mathrm{CO}_{2}$; Cucumis melo L.; cultivares; Oidium sp. 


\section{Introduction}

The atmospheric $\mathrm{CO}_{2}$ concentration exceeded 410 ppm, estimated to reach $1000 \mathrm{ppm}$, in the Representative Concentration Routes (RCP) 8.5, until 2100 (IPCC, 2013; NOAA, 2019). One consequence of the increase in atmosphere $\mathrm{CO}_{2}$ is the air temperature rise, with increases expected to range from 1.7 to $4.8^{\circ} \mathrm{C}$ by the end of the century (IPCC, 2013).

In the last 10 years, the number of studies that evaluated the interaction of $\mathrm{CO}_{2}$ and temperature in the severity of diseases in plants has increased. However, some studies still evaluate only the isolated effect of $\mathrm{CO}_{2}$. Thus, there is a need to intensify research related to the interaction of these climatic elements, since there is no way to dissociate the increase in $\mathrm{CO}_{2}$ concentration from the temperature increase.

Changes in the atmosphere chemical composition as well as in the air temperature may modify the phytosanitary structure of the different crops. Increased $\mathrm{CO}_{2}$ and temperature can affect both host and pathogen, altering the temporal and spatial distribution of plant diseases (Debela \& Tola, 2018; Pathak et al., 2018).

Increasing $\mathrm{CO}_{2}$ concentration induces stomatal closure, consequently improving water use efficiency, protecting against water stress and increasing plant defense (Abdelgawad et al., 2016). In addition, this gas acts positively on increasing plant biomass (Tozzi \& Ghini, 2016). However, this increase may represent a larger amount of tissue to be infected by leaf pathogens, facilitating growth, sporulation and dissemination (Debela \& Tola, 2018). In the pathogen, increased $\mathrm{CO}_{2}$ can have a direct effect on virulence (Debela \& Tola, 2018), altering its development (Pathak et al., 2018) and their survival rate (Elad \& Pertot, 2014). As $\mathrm{CO}_{2}$, temperature can also directly affect on plant growth and development, acting as an essential element in pathogens' life cycle, increasing or decreasing the risk of epidemics (Pathak et al., 2018; Ziska et al., 2018). However, these responses may vary between different pathosystems and geographic regions, either in the short or long term.

Melon powdery mildew, commonly caused by the fungus Podosphaera xanthii Braun and Shishkoff (anamorphic Oidium sp.) is one of the main leaf diseases of the crop in the Northeast (Reis et al., 2005). Powdery mildew is favored by environmental conditions of low relative humidity (below $50 \%$ ) and temperatures around $20{ }^{\circ} \mathrm{C}$ to $25{ }^{\circ} \mathrm{C}$ (Rabelo, 2017). The disease has great economic importance and can cause severe damage to plants, with considerable losses in production (Costa, 2017). However, there are no reports in Brazil about the influence of increased $\mathrm{CO}_{2}$ concentration and temperature on the severity of melon powdery mildew.

Thus, the objective of this study was to evaluate the impact of increased carbon dioxide concentration and temperature on melon powdery mildew.

\section{Material and Methods}

The experiment was carried out in growth chambers (Fitotron type) with control of temperature, $\mathrm{CO}_{2}$, humidity and light at Embrapa Semiarid, Petrolina-PE, Brazil.
The temperature regimes used were $\mathrm{T} 1: 20-26-33{ }^{\circ} \mathrm{C}(20$ ${ }^{\circ} \mathrm{C}$ : from $8 \mathrm{pm}$ to $6 a \mathrm{~m}, 26{ }^{\circ} \mathrm{C}$ : from $6 a \mathrm{~m}$ to $10 \mathrm{am}$ and $33{ }^{\circ} \mathrm{C}$ : from 10am to $3 \mathrm{pm} ; 26^{\circ} \mathrm{C}$ : from $3 \mathrm{pm}$ to $8 \mathrm{am}$ ) and T2: $24-30-37$ ${ }^{\circ} \mathrm{C}\left(24{ }^{\circ} \mathrm{C}\right.$ : from $8 p m$ to $6 a m ; 30{ }^{\circ} \mathrm{C}$ from 6am to $10 \mathrm{am} ; 37^{\circ} \mathrm{C}$ : from $10 \mathrm{am}$ to $3 \mathrm{pm} ; 30^{\circ} \mathrm{C}$ : from $3 \mathrm{pm}$ to $\left.8 \mathrm{pm}\right)$. The temperature values were evaluated according to the minimum, medium and maximum temperatures at the São Francisco River Valley, which varied from $18-22,25-27$ and $32-34{ }^{\circ} \mathrm{C}$, respectively. To evaluate the effect of the increased $\mathrm{CO}_{2}$ concentration, the seedlings were maintained on growth chambers with 410 ppm to $770 \mathrm{ppm}$ of $\mathrm{CO}_{2}$.

Seeds of the cultivars Araguaia, Awton, Eldorado, Gladial, Gold, Hibix, Natal, Juazeiro and Sancho were sowed in plastic cups with $500 \mathrm{~mL}$ of capacity containing soil and manure $(80 \%$ soil and $20 \%$ manure). The plants were kept in fitotron growth chambers from sowing until the end of the experiment.

The initial inoculum Oidium sp. (teleomorphic Podosphaera xanthii) was obtained from conidia of naturally infected melon leaves, collected in Petrolina-PE, Brazil. For the multiplication and maintenance of the inoculum, healthy melon seedlings of cultivar Sancho were inoculated every 15 days and kept in a greenhouse.

Melon plants with fully open cotyledonary leaves were inoculated with a suspension of $10^{5}$ conidia / $\mathrm{ml}$ in $0.01 \%$ Tween 20 solution by spraying until dripping. Immediately after inoculation, the seedlings were submitted to the treatments mentioned above.

To quantify the severity of the disease, the percentage of diseased leaf area was evaluated by adapting the diagrammatic scale developed by Buffara et al. (2014), with the intervals of $1,5,12,25,50,75$ and $100 \%$ of the diseased leaf area. Severity values were used to calculate the area under disease progress curve (AUDPC) (Shaner \& Finney, 1977). The incubation period, determined by the number of days between inoculation and onset of mycelial mass was evaluated. At the end of the experiment, at nine days after inoculation, $1 \mathrm{~cm}$ diameter circular segments were cut from cotyledonary leaves to quantify sporulation. These segments were transferred to falcon tubes containing $1 \mathrm{~mL}$ of Triton $\mathrm{X}-100(0.05 \%)$. The tubes were vortexed for 30 seconds and then in an orbital shaker for 30 minutes at $150 \mathrm{rpm}$. The number of conidia / $\mathrm{ml}$ was estimated using the Neubauer Chamber.

A completely randomized design in a $9 \times 2 \times 2$ factorial scheme (cultivars $x$ temperature $x \mathrm{CO}_{2}$ concentration) was used, with four replications and experimental plot of four plants. Severity values were used to calculate the area under the disease progress curve (AUDPC) which is obtained by calculating AUDPC $=\sum\left(\left(y_{i}+y_{i+1}\right) / 2\right) x d t$, where, $y_{i}+y_{i+1}$ are the values observed in two consecutive evaluations and dti is the interval between evaluations (Shaner \& Finney, 1977).

Data were submitted to variance analysis and means were compared by the Scott-Knott's test using the Sisvar software (Ferreira, 2011). 


\section{Results and Discussion}

In the summary of the variance analysis, according to the $\mathrm{F}$ value, it was observed that the interaction $\left[\mathrm{CO}_{2}\right] \mathrm{x}$ Temperature $x$ Cultivars was significant for the area under the disease progress curve, based on the powdery mildew severity in melon (Table 1). This result indicates that the severity of powdery mildew may vary among cultivars when submitted to different temperatures and carbon dioxide concentrations. On the other hand, fungus sporulation was not influenced by the different cultivars tested (Table 1).

The severity of plant diseases may vary depending on the host genotype and climatic conditions. By analyzing the variables separately, it was found that the cultivar Hibix, yellow type, presented higher AUDPC: 251.22 (Figure 1). The cultivars Araguaia, Awton, Gladial and Juazeiro presented the lowest AUDPC values. However, even presenting a statistical difference between AUDPC values, the disease severity was $50 \%$, which indicates that all materials tested are susceptible, requiring the adoption of control measures.

Regarding the carbon dioxide concentration, plants grown in a $\mathrm{CO}_{2}$-enriched environments presented a reduction of $49 \%$ in powdery mildew severity, with AUDPC of 131.55 (Figure 2).

Table 1. Results of the variance analysis for cultivar, $\mathrm{CO}_{2}$ and temperature for area under the disease progress curve (AUDPC), based on the powdery mildew severity, and sporulation in melon seedlings.

\begin{tabular}{lcc}
\hline \multirow{2}{*}{ Parameters } & \multicolumn{2}{c}{ Valor $\mathrm{F}$} \\
\cline { 2 - 3 } & AUDPC & Sporulation \\
\hline Cultivar & $10.195^{*}$ & 1.705 \\
$\mathrm{CO}_{2}$ & $511.586^{*}$ & $6.924^{*}$ \\
Temperature & $695.847^{*}$ & $42.320^{*}$ \\
Cultivar $\times \mathrm{CO}_{2}$ & $4.501^{*}$ & 0.888 \\
Cultivar $\times$ Temperature & $8.159^{*}$ & 1.825 \\
$\mathrm{CO}_{2} \times$ Temperature & $89.772^{*}$ & $6.946^{*}$ \\
Cultivar $\times \mathrm{CO}_{2} \times$ Temperature & $7.307^{*}$ & 0.923 \\
\hline
\end{tabular}

*Significance level at $p<0.05$.

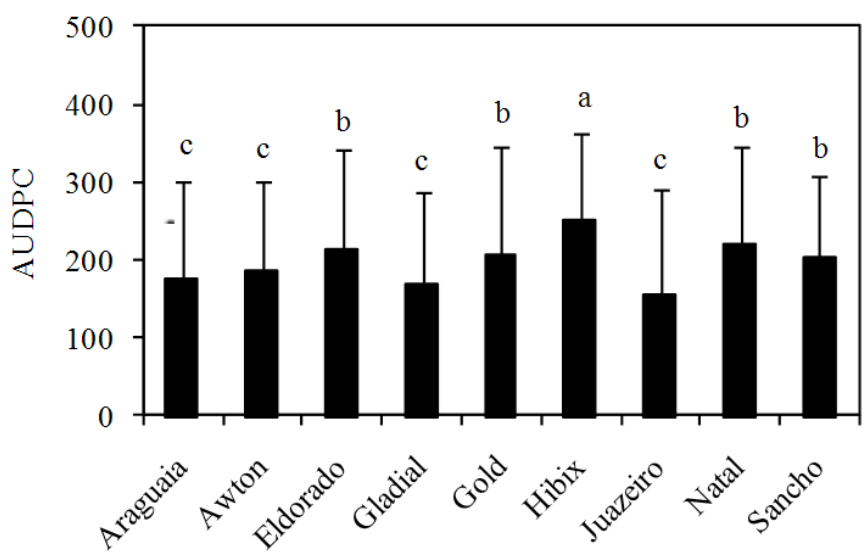

Melon cultivars

* Averages followed by the same lowercase letter are not significantly different by the Scott-Knott's test at $5 \%$ of probability.

Figura 1. Area under disease progress curve (AUDPC) values for severity of powdery mildew in different cultivars of melon.

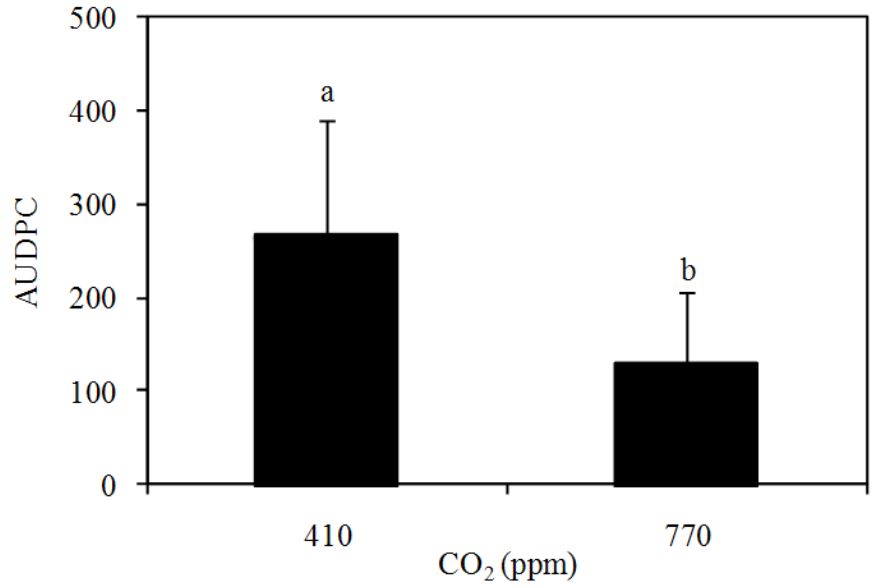

* Averages followed by the same lowercase letter are not significantly different by the $\mathrm{F}$ test at $5 \%$ of probability.

Figure 2. Area under disease progress curve (AUDPC) values for severity of powdery mildew in melon at different carbon dioxide $\left(\mathrm{CO}_{2}\right)$ concentrations.

The evaluation of the effect of increased $\mathrm{CO}_{2}$ concentration was reported for different genera and species of powdery mildew, showing variation in the response of the different crops studied. For the cucumber (Cucumis sativus L.) powdery mildew (P. xanthii) (Itagaki et al., 2015) and barley (Hordeum vulgare L.) powdery mildew (Blumeria graminis. Marchal) (Mikkelsen et al., 2014), the increase in $\mathrm{CO}_{2}$ concentration resulted in a reduction of the disease severity. In Arabidopsi thaliana the severity caused by the genra Erysiphe cichoracearum DC. ex. Mérat increased in $\mathrm{CO}_{2}$-enriched environment (Lake \& Wade, 2009). For zucchini (Curcubita pepo L.) (Pugliese et al., 2012), wheat (Triticum spp.) (Matic et al., 2018) and grapevine (Vitis vinifera L.) (Pugliese et al., 2010) the increase of the $\mathrm{CO}_{2}$ did not affected the severity of the powdery mildew caused by $P$. xanthii, $B$. graminis and Erysiphe necator Schwein, respectively.

In pathosystems involving different genera of rust, the behavior was also similar. Reduction in the disease severity was observed for coffee (Coffea spp.) (cultivar Catuaí Vermelho IAC 144) - Hemileia vastatrix Berk. \& Br. (Tozzi \& Ghini, 2016), eucalyptus (Eucalyptus spp.) - Puccinia psiidi Winter (Ghini et al., 2015) and soy ((Glycine max (L.) Merrill) - Phakospsora pachyrhizi Sidow (Lessin \& Ghini, 2009). On the other hand, the increase of the disease occurred in alfafa (Medicago sativa L.) - Uromyces striatus J. Schrot (Santos, 2015). The coffee cultivar 'Obatã IAC 1669-20' was not influenced by the increase in $\mathrm{CO}_{2}$ concentration in the rust severity (H. vastatrix) (Tozzi \& Ghini, 2016). This diversity of responses confirms the importance of studies for each pathosystem, evaluating their specificities.

As carbon dioxide, temperature also influenced AUDPC, both by its direct effect on the pathogen cycle and host plant development. For melon powdery mildew, the temperature range 20-26-33 ${ }^{\circ} \mathrm{C}$ increased the AUDPC in leaves (Figure 3 ). High temperatures, such as the $24-30-37{ }^{\circ} \mathrm{C}$ regime, are unfavorable for the development of Oidium sp.. In the literature, the differentiated response of pathosystems can also be verified under different temperatures. For the fungus 


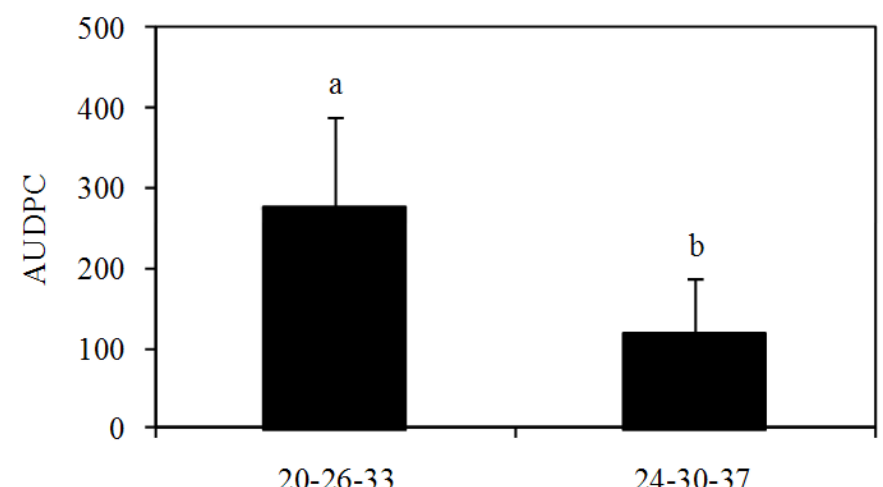

Temperature regimes $\left({ }^{\circ} \mathrm{C}\right)$

* Averages followed by the same lowercase letter are not significantly different by the $\mathrm{F}$ test at $5 \%$ of probability.

Figure 3. Area under disease progress curve (AUDPC) values for severity of powdery mildew in melon under two temperature regimes.

B. graminis, the temperature increase $\left(26-30{ }^{\circ} \mathrm{C}\right)$ inhibited fungal growth, reducing the severity of wheat powdery mildew (Matic et al., 2018). In the northern hemisphere, temperature increases favored the severity of zucchini powdery mildew caused by $P$. xanthii fungus (Pugliese et al., 2012). Increasing temperature alters the progress of plant disease (Chakraborty \& Newton, 2011; Debela \& Tola, 2018). This is due to the decisive role of this climate element in the cycle of pathogen-host relationships and can act from spore germination to reproduction. Thus, temperature acts on the speed and extent of infection, determining the severity of the disease (Angelotti et al., 2017).

Understanding the influence of each variable on the occurrence of powdery mildew is relevant. However, the increase in $\mathrm{CO}_{2}$ concentration will cause an increase in air temperature, so it is understood the need to evaluate the interaction of these factors in the occurrence and severity of this disease. In addition, studies point to the specificity of the response of genetic materials to environmental changes, highlighting the importance of research that indicates the behavior of different cultivars to climate change. Through the triple interaction it was found that the highest powdery mildew severity occurred in an environment with $410 \mathrm{ppm}$ of $\mathrm{CO}_{2}$ and temperature regime of $20-26-33{ }^{\circ} \mathrm{C}$ for all evaluated cultivars
(Table 2). Under these conditions, the highest AUDPC values were observed in the leaves of cultivars Eldorado, Gold, Hibix and Natal. The cultivars Eldorado, Gladial and Gold presented the same behavior, with reduction of disease severity due to temperature increase, and in environment enriched with $\mathrm{CO}_{2}$. The Awton, Hibix and Sancho cultivars maintained at 770 ppm and $20-26-33{ }^{\circ} \mathrm{C}$ and $410 \mathrm{ppm}$ and $24-30-37{ }^{\circ} \mathrm{C}$ showed no statistical difference in AUDPC for these two environments (Table 2). These values of $\mathrm{CO}_{2}$ concentration (410 ppm) and temperature regime $\left(20-26-33^{\circ} \mathrm{C}\right)$ were used as they represent the current climate scenario of the São Francisco Valley. The development of the powdery mildew in the field confirms its favorability in milder seasons for the region.

It is noteworthy that nowadays the evaluated cultivars are highly susceptible to powdery mildew. In a future climate scenario, the economic importance of the disease may be reduced, as for this pathogen, environmental conditions will be unfavorable due to the increase in temperature and carbon dioxide concentration. The cultivars Eldorado, Gladial and Gold stood out with the lowest severity with increasing temperature and carbon dioxide concentrations (Table 2). However, in the long run this response will depend on the adaptive capacity of the fungus to the new climatic conditions.

As already discussed in the evaluation of the isolated variables, the interaction $\mathrm{CO}_{2} \times$ temperature also presented differentiated response of pathosystems involving different genera of powdery mildew, which may result in reduction, increase or no effect on disease severity (Pugliese et al., 2012; Pugliese et al., 2010; Matic et al., 2018; Mikkelsen et al., 2014). Similar results were found in grapevine and wheat plants, where the reduction in powdery mildew development also occurred in an environment enriched with $\mathrm{CO}_{2}$ and with increased air temperature (Pugliese et al., 2010; Matic et al., 2018). In barley, powdery mildew severity was reduced at an average temperature of $21.5^{\circ} \mathrm{C}$ and an environment with a $\mathrm{CO}_{2}$ concentration of $700 \mathrm{ppm}$ (Mikkelsen et al., 2014).

The severity of zucchini powdery mildew increased with the combination of $800 \mathrm{ppm}$ of $\mathrm{CO}_{2}$ and temperature regime of $22{ }^{\circ} \mathrm{C}$ at night and $28{ }^{\circ} \mathrm{C}$ during the day (Pugliese et al., 2012). Zucchini powdery mildew is the same as melon powdery mildew. However, it is noteworthy that the temperature increase was favorable, since this study was conducted in

Table 2. Interaction effect of cultivar $\mathrm{x}$ temperature regime $\mathrm{x} \mathrm{CO}_{2}$ concentration in the area under disease progress curve (AUDPC) values for severity of powdery in melon.

\begin{tabular}{|c|c|c|c|c|}
\hline \multirow{2}{*}{ Cultivar } & \multicolumn{2}{|c|}{$20-26-33^{\circ} \mathrm{C}$} & \multicolumn{2}{|c|}{$24-30-37{ }^{\circ} \mathrm{C}$} \\
\hline & 410ppm & 770ppm & 410ppm & 770ppm \\
\hline Araguaia & $348.92 \mathrm{Ab}$ & $75.63 \mathrm{Cd}$ & $219.33 \mathrm{Ba}$ & $78.13 \mathrm{Cb}$ \\
\hline Awton & $363.25 \mathrm{Ab}$ & $146.75 \mathrm{BC}$ & $169.88 \mathrm{Bb}$ & $74.13 \mathrm{Cb}$ \\
\hline Eldorado & $386.69 \mathrm{Aa}$ & $257.50 \mathrm{Ba}$ & $151.56 \mathrm{Cb}$ & $58.75 \mathrm{Db}$ \\
\hline Gladial & $337.81 \mathrm{Ab}$ & 193.92 Ba & $115.00 \mathrm{Cc}$ & $37.06 \mathrm{Db}$ \\
\hline Gold & $419.13 \mathrm{Aa}$ & $203.19 \mathrm{Bb}$ & $127.50 \mathrm{Cc}$ & $77.33 \mathrm{Db}$ \\
\hline Juazeiro & $364.67 \mathrm{Ab}$ & $149.75 \mathrm{BC}$ & $36.00 \mathrm{Cd}$ & $75.92 \mathrm{Cb}$ \\
\hline Sancho & $336.69 \mathrm{Ab}$ & $221.69 \mathrm{Bb}$ & $170.08 \mathrm{Bb}$ & $87.00 \mathrm{Cb}$ \\
\hline
\end{tabular}

*Means followed by the same lowercase letter in columns and uppercase letter in lines are not different according to Scott-Knott's test at $5 \%$ of probability. 

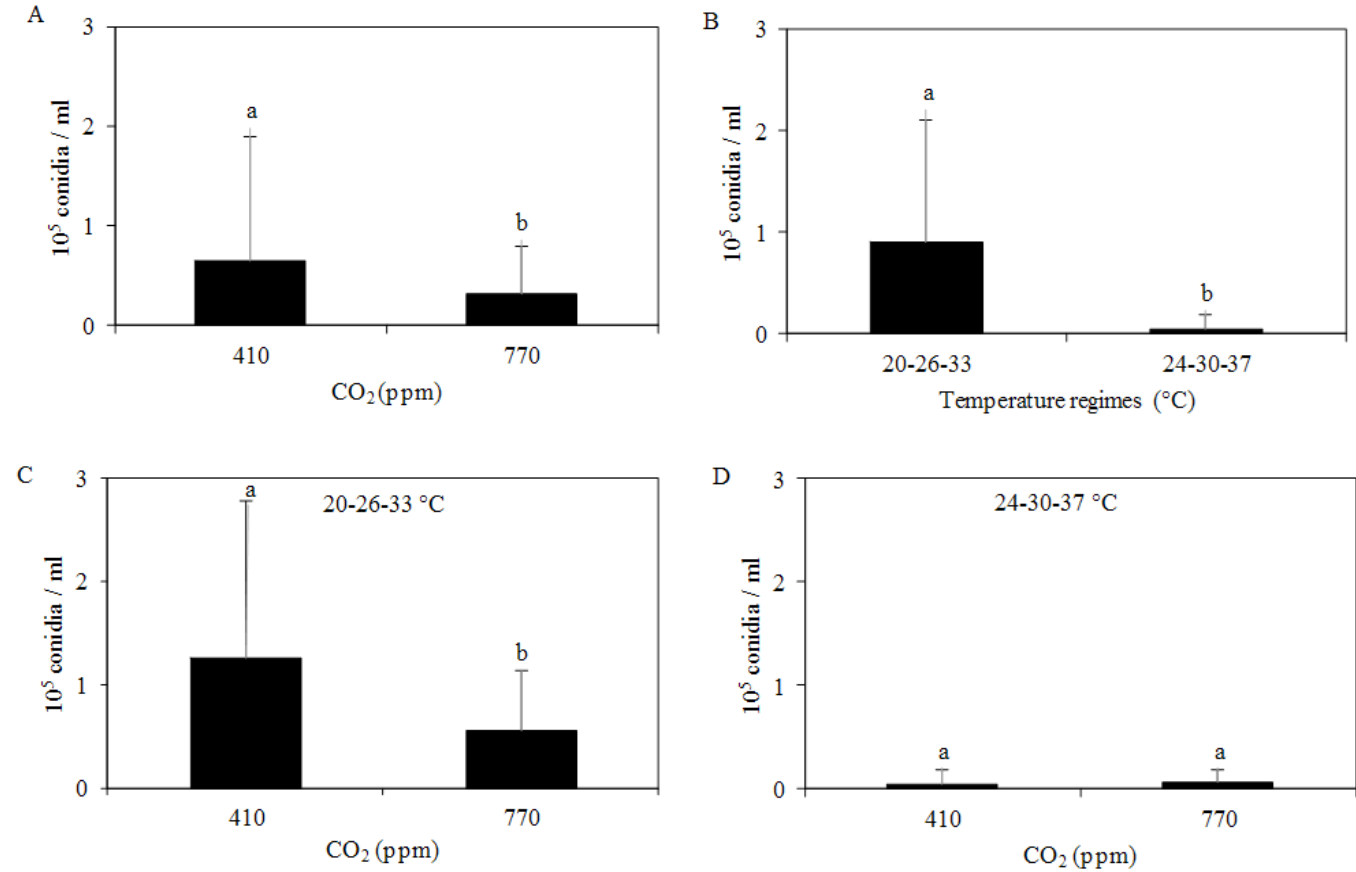

* Means followed by the same lowercase letter in columns and uppercase letter in lines are not different according to $\mathrm{F}$ test at $5 \%$ of probability.

Figure 4. Sporulation of melon powdery mildew at different $\mathrm{CO}_{2}$ concentrations $(\mathrm{A})$; at two temperature regimes (B) and at a temperature range of $20-26-33^{\circ} \mathrm{C}(\mathrm{C})$ and $24-30-37^{\circ} \mathrm{C}(\mathrm{D})$ associated with different $\mathrm{CO}_{2}$ concentrations (410 and 770 ppm).

the Northern Hemisphere, and the low temperature was 18 ${ }^{\circ} \mathrm{C}$ night and $24{ }^{\circ} \mathrm{C}$ day, with a daily average of $21{ }^{\circ} \mathrm{C}$. Thus, the average of $25^{\circ} \mathrm{C}$ is also within the favorable temperature range for the development of powdery mildew in Brazil.

In an environment with the current $\mathrm{CO}_{2}$ concentration (410 ppm), the incubation period ranged from three to four days. In the temperature regime of $20-26-33{ }^{\circ} \mathrm{C}$, only the cultivar Gladial presented the mycelium mass after four days of inoculation, and the other cultivars after three days. At the highest temperature, $24-30-37^{\circ} \mathrm{C}$, the cultivars Araguaia, Awton, Gold, Hibix and Natal had the incubation period of three days and the remaining four days. In an environment enriched with $\mathrm{CO}_{2}(770 \mathrm{ppm})$, the incubation period had a greater variation, between four and seven days. At 20-26-33 ${ }^{\circ} \mathrm{C}$, the period was four days for Awton, Gold, Hibix and Natal cultivars. For the other cultivars this period was five days. At the highest temperature, the cultivar Juazeiro presented the longest incubation period, seven days. The other cultivars presented visible mycelial mass on five days after inoculation.

The lower progress of powdery mildew on melon in a $\mathrm{CO}_{2}-$ enriched environment and at $24-30-37{ }^{\circ} \mathrm{C}$ may have occurred due to physiological changes in the seedling. According to Bencze et al. (2015), increased $\mathrm{CO}_{2}$ concentration alters plant metabolism, physiology and development, with changes in plant resistance to leaf pathogens, impacting infection and disease progression. Thus, in a climate change scenario, the reduction in the severity of melon powdery mildew could result in an update of management techniques for disease control.

The sporulation of Oidium sp. in melon was significantly influenced by temperature, $\mathrm{CO}_{2}$ concentration and temperature $\mathrm{x} \mathrm{CO}_{2}$ interaction. Thus, increasing temperature and $\mathrm{CO}_{2}$ concentration reduced the inoculum amount (Figure
4). In watermelon, Sphaerotheca fuliginea sporulation was also reduced with temperature increase from $20{ }^{\circ} \mathrm{C}$ to 50 ${ }^{\circ} \mathrm{C}$ (Suleiman et al., 2016). The sporulation of Microsphaera diffusa Cke. \& Pk. in soy did not have the influence of this gas (Lessin \& Ghini, 2009). For sporulation, no studies were found that report the effect of temperature $x \mathrm{CO}_{2}$ interaction. As conidial production is related to disease intensity and also to the inoculum available for new infections, the evaluation of this component of the infection cycle is important. For the fungus Oidium sp. in melon, the result proves the reduction of the disease favorability in a scenario of increased carbon dioxide concentration and consequent temperature increase.

The sporulation of Microsphaera diffusa Cke. \& Pk. in soy was not influenced by the (Lessin \& Ghini, 2009). For sporulation, no studies were found that report the effect of temperature $\times \mathrm{CO}_{2}$ interaction. As conidial production is related to disease intensity and to the inoculum available for new infections, the evaluation of this component of the infection cycle is important. For the fungus Oidium sp. in melon, the result proves the reduction of the disease favorability in a scenario of increased carbon dioxide concentration and consequent temperature increase.

\section{Conclusions}

Increasing temperature and $\mathrm{CO}_{2}$ concentration, as well as the interaction of these factors, reduce the severity of melon powdery mildew and the sporulation of Oidium sp. (teleomorphic $P$. xanthii).

The increase in $\mathrm{CO}_{2}$ and temperature provided different responses for melon cultivars, with $50 \%$ of severity, indicating high susceptibility. 
The incubation period of melon powdery mildew increases with increasing $\mathrm{CO}_{2}$ and temperature.

\section{Literature Cited}

Abdelgawad, H.; Zinta, G.; Beemster, G.T.; Janssens, I.A.; Asard, H. Future climate $\mathrm{CO}_{2}$ levels mitigate stress impact on plants: increased defense or decreased challenge? Frontiers in Plant Science, v.7, article 556, 2016. https://doi.org/10.3389/fpls.2016.00556.

Angelotti, F.; Ghini, R.; Bettiol, W. Como o aumento da temperatura interfere nas doenças de plantas? In: Bettiol, W.; Hamada, E.; Angelotti, F.; Auad, A. M.; Ghini, R. (Orgs.). Aquecimento global e problemas fitossanitários. Brasília: Embrapa, 2017. p.116-146.

Bencze, S.; Komáromi, J.; Vida, G.; Puskás, K.; Balla, K.; Veisz, O. Impact of elevated atmospheric $\mathrm{CO}_{2}$ level on powdery mildew (Blumeria graminis f.sp. tritici) severity in wheat depends on the Pathotype $\times$ Genotype interaction. Procedia Environmental Sciences, v.29, p.232-233, 2015. https://doi.org/10.1016/j.proenv.2015.07.288.

Buffara, C.R.S.; Angelotti, F.; Vieira, R.A.; Bogo, A.; Tessmann, D.J.; Bem, B.P. Elaboration and validation of a diagrammatic scale to assess downy mildew severity in grapevine. Ciência Rural, v.44, n.8, p.1384-1391, 2014. https://doi.org/10.1590/0103$8478 \mathrm{cr} 20131548$.

Chakraborty, S.; Newton, A.C. Climate change, plant diseases, and food security, an overview. Plant Pathology, v.60, n.1, p.2-14, 2011. https://doi.org/10.1111/j.1365-3059.2010.02411.x.

Costa, N.D. (Org.). A cultura do melão. Brasília: Embrapa, 2017. 202p.

Debela, C.; Tola, M. Effect of elevated $\mathrm{CO}_{2}$ and temperature on crop disease interactions under rapid climate change. International Journal of Environmental Sciences \& Natural Resources, v.13, n.1, e555851, 2018. https://juniperpublishers.com/ijesnr/IJESNR. MS.ID.555851.php. 29 Mar. 2019.

Elad, Y.; Pertot, I. Climate change impacts on plant pathogens and plant diseases. Journal of Crop Improvement, v.28, n.1, p.99-139, 2014. https://doi.org/10.1080/15427528.2014.865412.

Ferreira, D. F. Sisvar: um sistema computacional de análise estatística. Ciência e Agrotecnologia, v.35, n.6, p.1039-1042, 2011. https:// doi.org/10.1590/S1413-70542011000600001.

Ghini, R.; MacLeod, R.E.O.; Santos, M.S.; Silva, C.E.O. Elevated atmospheric carbon dioxide concentration increases eucalyptus plantlets growth and reduces diseases severity. Procedia Environmental Sciences, v.29, p.206-207, 2015. https://doi. org/10.1016/j.proenv.2015.07.264. http://dx.doi.org/10.1590/ S1413-70542011000600001.

Intergovernmental Panel on Climate Change - IPCC. 2013: summary for policymakers. In: Stoker, T.F.; Qin, D.; Plattner, G.K.; Tignor, M.; Allen, S.K.; Boschung, J.; Nauels, A.; Xia, Y.; Bex, V.; Midgley, P.M. (Eds.). Climate change 2013: the physical science basis. Contribution of working group I to the fifth assessment report of the Intergovernmental Panel on Climate Change. Cambridge; New York: Cambridge University Press, 2013. 3-29p. https://www.ipcc. ch/site/assets/uploads/2018/03/WG1AR5_SummaryVolume_ FINAL.pdf. 03 Mar. 2019.

Itagaki, K.; Shibuya, T.; Tojo, M.; Enfo, R.; Kitaya, Y. development of powdery mildew fungus on cucumber leaves acclimatized to different $\mathrm{CO}_{2}$ concentrations. Hortscience, v.50, n.11, p.16621665, 2015. https://doi.org/10.21273/HORTSCI.50.11.1662.
Lake, J.A.; Wade, R.N. Plant-pathogen interactions and elevated $\mathrm{CO}_{2}$ : morphological changes in favour of pathogens. Journal of Experimental Botany, v.60, n.11, p.3123-3131, 2009. https://doi. org/10.1093/jxb/erp147.

Lessin, R.C.; Ghini, R. Efeito do aumento da concentração de $\mathrm{CO}_{2}$ atmosférico sobre o oídio e o crescimento de plantas de soja. Tropical Plant Pathology, v.34, n.6, p.385-392, 2009. https://doi. org/10.1590/S1982-56762009000600004.

Matic, S.; Cucu, M.A.; Garibaldi, A.; Gullino, M.L. Combined effect of $\mathrm{CO}_{2}$ and temperature on wheat powdery mildew development. The Plant Phatology Journal, v.34, n.4, p.316-326, 2018. https:// doi.org/10.5423/PPJ.OA.11.2017.0226.

Mikkelsen, B.L.; Jorgensen, R.B.; Lyngkjaer, M.F. Complex interplay of future climate levels of $\mathrm{CO}_{2}$, ozone and temperature on susceptibility to fungal diseases in barley. Plant Pathology, v.64, n.2, p.319-327, 2014. https://doi.org/10.1111/ppa.12272.

National Oceanic and Atmospheric Administration - NOAA. Trends in atmospheric carbon dioxide. https://www.esrl.noaa.gov/gmd/ ccgg/trends. 02 Ago. 2019.

Pathak, R.; Singh, S.K.; Tak, A.; Gehlot, P. Impact of climate change on host, pathogen and plant disease adaptation regime: a review. Biosciences Biotechnology Research Asia, v.15, n.3, p.529-540, 2018. https://doi.org/10.13005/bbra/2658.

Pugliese, M.; Gullino, M.L.; Garibaldi, A. Effects of elevated $\mathrm{CO}_{2}$ and temperature on interactions of grapevine and powdery mildew: first results under phytotron conditions. Journal of Plant Diseases and Protection, v.117, n.1, p.9-14, 2010. https://doi.org/10.1007/ BF03356327.

Pugliese, M.; Liu, J.; Titone, P.; Garibaldi, A.; Gullino, M.L. Effects of elevated $\mathrm{CO}_{2}$ and temperature on interactions of zucchini and powdery mildew. Phytopathologia Mediterranea, v.51, n.3, p.480-487, 2012. https://doi.org/10.14601/Phytopathol_ Mediterr-9801.

Rabelo, H.O. Reação de genótipos de meloeiro ao oídio das cucurbitáceas, métodos para identificação de raças e progresso de doença. Jaboticabal: Faculdade de Ciências Agrárias e Veterinárias, Universidade Estadual Paulista, 2017. 76 f. Tese Doutorado. http://hdl.handle.net/11449/148912. 09 Abr. 2019.

Reis, A.; Dias, R.C.S.; Aragão, F.A.S.; Boiteux, L.S. Caracterização do perfil patogênico de isolados de Podosphaera xanthii obtidos em cucurbitáceas na região Nordeste do Brasil. Horticultura Brasileira, v. 23 , n. 2, suplemento, 2005. CD-Rom. https://www.alice.cnptia. embrapa.br/bitstream/doc/156120/1/OPB868.pdf. 09 Abr. 2019.

Santos, M. S. Efeito do $\mathrm{CO}_{2}$ sobre a qualidade nutricional, ferrugem e fusariose da alfafa. Botucatu: Faculdade de Ciências Agronômicas, Universidade Estadual de Paulista, 2015. 55 f. Tese Doutorado. http://hdl.handle.net/11449/126398. 29 Mar. 2019.

Shaner, G.; Finney, R.F. The effects of nitrogen fertilization on the expression of show-mildwing in knox wheat. Phytopathology, v.67, n.8, p.1051-1055, 1977. https://doi.org/10.1094/ Phyto-67-1051.

Suleiman, H.M.; Hayatu, M.; Kutama, A.S. Effects of temperature on the germination, sporulation, and in - vivo infection of Sphaerotheca fuliginea (powdery mildew) on water melon (Citrullus lanathus. L). Bayero Journal of Pure and Applied Sciences, v.9, n.1, p.82-86, 2016. https://doi.org/10.4314/bajopas.v9i1.13. 
Tozzi, F.R.O.; Ghini, R. Impacto do aumento da concentração atmosférica de dióxido de carbono sobre a ferrugem e o crescimento do cafeeiro. Pesquisa Agropecuária Brasileira, v.51, n.8, p.933-941, 2016. https://doi.org/10.1590/S0100-204X2016000800005.
Ziska, L.H., Bradley, B.; Wallace, R.; Bargeron, C.T. Climate change, carbon dioxide, and pest biology, managing the future: coffee as a case study. Agronomy, v.8, n.8, article 152, 2018. https://doi. org/10.3390/agronomy8080152. 